\title{
The Nutritional Value Enhancement of Oil Palm Empty Fruit Bunches as Animal Feed Using the Fungus Coprinus Comatus, with Different Numbers of Inoculums and Incubation Times
}

\author{
Sitti Sabariyah ${ }^{*}$, Rusdi $^{2}$, Damry $^{2}$, Asriani Hasanuddin $^{2}$ \\ ${ }^{1}$ Faculty of Agriculture, Alkhairaat University, Palu 94221, Indonesia \\ ${ }^{2}$ Faculty of Animal Husbandry and Fisheries, Tadulako University, Palu 94118, Indonesia
}

Corresponding Author Email: st.sabariyah.unisa@gmail.com

https://doi.org/10.18280/ijdne.160304

Received: 26 April 2021

Accepted: 10 June 2021

\section{Keywords:}

white-rot fungi, oil palm empty fruit

bunches, lignin, cellulose

\begin{abstract}
This study aimed to increase the nutritional value of oil palm empty bunches (EFB) as ruminant animal feed by using biological treatment. To achieve this, five fungi species were used, including Trametes Versicolor, Lentinula edodes, Coprinus comatus, Pleurotus sajor-caju, and Trichoderma sp, which were inoculated for 20 days. Furthermore, the study consisted of 2 stages, in the first, the five species were tested for their degradability to lignin. In the second, the results were analyzed for their degradation ability by treating several numbers of inoculums $(0.5 \mathrm{ml}, 0.75 \mathrm{ml}$, and $1.0 \mathrm{ml})$ at different incubation times (20,30, and 40 days). The results showed that the fungi treatment gave different lignin levels of oil palm empty fruit bunches compared to others. Furthermore, treatment with Coprinus comatus fungi produced the lowest lignin and the highest cellulose levels than others. This species works well compared to other fungi in the delignification of oil palm empty fruit bunches. With the use of Coprinus comatus, the lowest lignin and highest cellulose levels were obtained in a $0.5 \mathrm{ml}$ inoculum treatment and at 30 days incubation time, however, there was no interaction. Conclusively, this study indicated that the application of Coprinus comatus to oil palm empty fruit bunches reduces lignin levels and increases cellulose by $22.04 \%$ and $20 \%$, respectively. Consequently, there is an improved nutritional value of oil palm empty fruit bunches.
\end{abstract}

\section{INTRODUCTION}

The exploration of agricultural/plantation wastes is mainly conducted to address the limited availability of animal feed, including oil palm empty fruit branches. Furthermore, the Central Sulawesi Province has oil palm plantations covering 158,187 hectares with 316,781 tons of production [1]. The plantation produces biomass in empty fruit bunches, with about $3,680 \mathrm{~kg}$ fresh and $92.01 \%$ dry matter $(3,386 \mathrm{~kg}$ dry matter). Oil palm empty fruit bunches (OPEFB) contain chemical compounds with the potential to be used as animal feed [2]. Ishola et al. [3] reported that OPEFB comprises $82.4 \%$ hemicellulose and $17.6 \%$ lignin. Also, the remaining fiber from palm fruit juice has the shape of a thread. Its chemical composition includes $4 \%$ and $36 \%$ crude protein and fiber (26\% lignin), respectively [4].

However, the ability to digest and use these agricultural wastes has some limitations. These include their low lignin levels, which reduces their digestibility Furthermore, lignin as an antinutrient for livestock disturbs digestion and reduces the nutritional value of feed ingredients. Its content in oil palm empty bunches inhibits the conversion process of cellulose into simple sugars, which requires a process to release lignin [5]. One of the efforts to improve the digestibility of feed ingredients is through biological processing, which includes the use of lignocellulose-degrading fungi. Sarnklong et al. [6] in 2010, reported that the use of ligninolytic fungi including enzymes is a potential alternative with an environmentally friendly approach to change the nutritional value of rice straw. Several studies have also shown that white-rot fungi reduce lignin levels. Reddy et al. [7] reported that the use of Pleurotus sajor-caju in increasing the number of P.ostreatus and $P$. sajor-caju fungi will increase cellulolytic enzymes per dry weight of the material. Also, Belewu [8] used the Pleurotus sajor caju in sawdust media, and the remaining cotton was incubated for 60 days. The lignin content and the remaining cotton were reduced from $44.36 \%$ to $25.53 \%$ and $20 \%$ to $14.2 \%$, respectively. Cellulose was found in small quantity, which is $31.99 \%$ to $30.89 \%$ for sawdust and $23.72 \%$ to $21.8 \%$ for the remaining cotton. Furthermore, Trametes Versicolor and Pleurotus ostreatus had the first and second-best activity in breaking down lignin holocellulose in rice straw [9]. According to Islamiyati et al. [10], corn straw treated with Trichoderma sp provides body weight gain. Also, crude protein and fiber fraction were better than those without treatment of Phanerocaeta crysosporium and Trichoderma sp. The highest was in the treatment of Trichoderma sp 5\% with an incubation time of 2 weeks.

Mustabi [11] used a Coprinus comatus with an inoculum level of $5.0 \%, 7.5 \%$, and $10.0 \%(\mathrm{w} / \mathrm{w})$ at 15 and 30 days incubation period. The $10 \%$ inoculum level reduced lignin, crude fiber, and increase hemicellulose. Hermiati et al. [12] also found a weight loss of oil palm empty fruit bunches (OPEFB) fiber and an increase in the incubation time of OPF (oil palm fronds) until 3 weeks. However, there was no significant change in weight loss after. Fibers were found to 
be lower than OPF, which indicated that the mixed culture of $P$. crysosporium and $T$. Versicolor was more active in degrading OPF than OPEFB. Also, polysaccharides in the palm frond fibers are quickly degraded into glucose and xylose compared to empty fruit bunches (EFB).

This study, therefore, aims to determine the best white-rot fungi isolates from the five used in degrading lignin that produces low degradability of cellulose. Furthermore, the results were to obtain fungi that function optimally in degrading lignin in OPEFB media such that the great potential is useful as a forage substitute.

\section{MATERIALS AND METHODS}

The materials used in this study include empty fruit bunches of oil palm and five types of white-rot fungi, namely Trametes Versicolor, Lentinula edodes, Coprinus comatus, Pleurotus sajor-caju, and Trichoderma sp.

\section{Fungus Selection}

At this stage, five types of white-rot fungi were used, these include Trametes Versicolor, Lentinula edodes, Coprinus comatus, Pleurotus sajor-caju, and Trichoderma sp. The selection is based on the ability to degrade high lignin and low cellulose.

The following steps were conducted during the inoculum preparation stage. About 50 grams of PDA (potato dextrose agar) were dissolved in $1000 \mathrm{ml}$ of water, then heated until reddish. Subsequently, it was poured into a test tube as much as $3 \mathrm{ml}$ and then cooled. The five isolates were then inoculated onto oblique media up to 5 x $5=25$ and incubated for $2 \times 24$ hours.

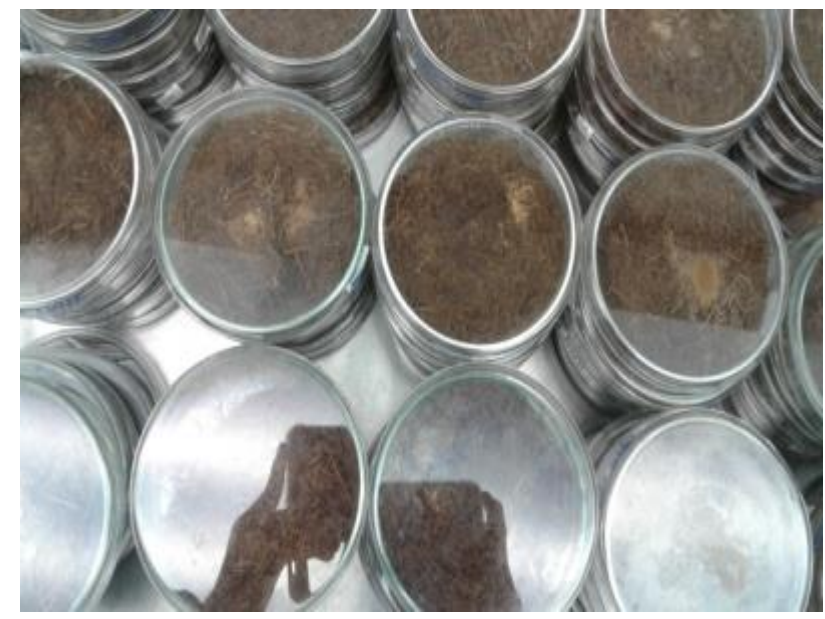

Figure 1. Oil palm empty fruit bunches ready to be inoculated with mushrooms

Figures 1, 2, and 3 show the processed oil palm empty fruit bunches ready to be inoculated with mushrooms and be fermented according to treatment. Mineral preparation was adopted for substrate enrichment. 1 liter of $\mathrm{KNO}_{3}$ mineral mixture $(2.33 \mathrm{~g} /$ liter $)$ is produced using bran $1 \%$ by weight of the substrate, $\mathrm{NH}_{4} \mathrm{NO}_{3}(0.5 \%), \mathrm{KCl}(0.05 \%), \mathrm{FeSO}_{4} 7 \mathrm{H}_{2} \mathrm{O}$ $(0.001 \%)$, and $\mathrm{CuSO}_{4}(0.0001 \%)$ (Ramli, 1995). About $10 \mathrm{ml}$ of minerals were given for every $10 \mathrm{~g}$ of OPEFB which was first milled with a size of 40 mesh. Also, $10 \mathrm{~g}$ of OPEFB was filled into Petri dishes, and minerals were added, then autoclaved and cooled.

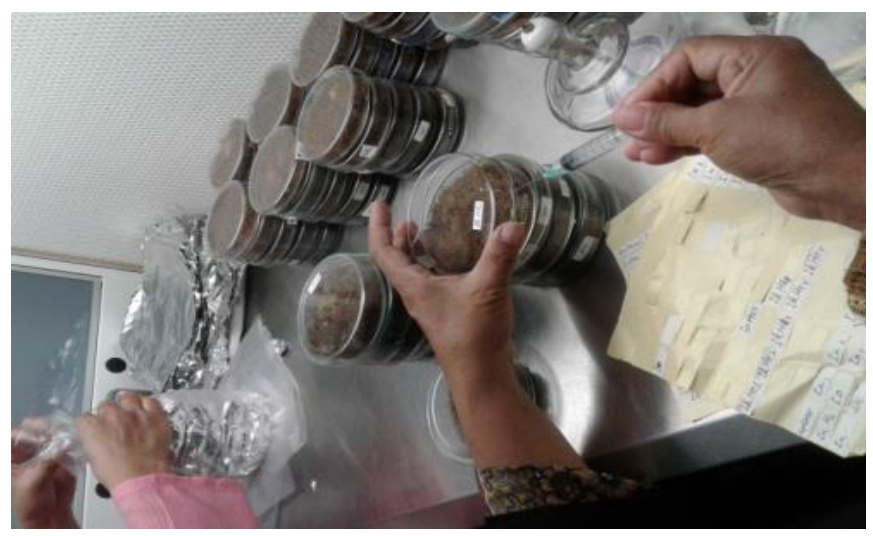

Figure 2. Mushroom inoculation process

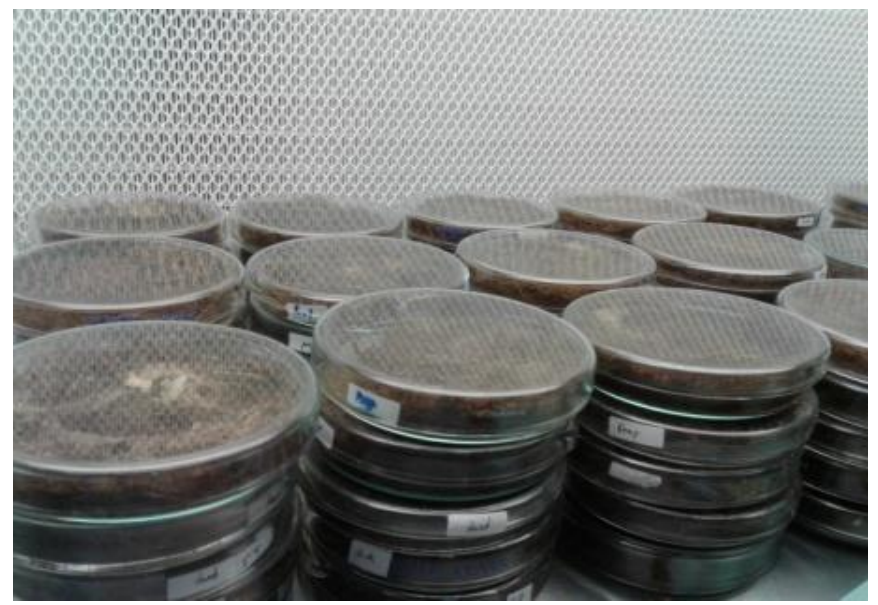

Figure 3. Oil palm empty fruit bunches ready to be fermented according to treatment

The following steps were carried out in the inoculation. The fungus grew in an inclined tube and was then made into a suspension solution with three dilutions. Each was sprayed onto the substrate using a $1 \mathrm{ml} / 10 \mathrm{~g}$ injector, then incubated for 20 days at room temperature $\left(27^{\circ} \mathrm{C}\right)$. There were five numbers of treatments with five replications, which makes a total of 25 units. Furthermore, analysis was carried out to determine cellulose and lignin levels.

\section{Analysis of the number of inoculum and incubation time}

The fungi selected in the previous stage were tested by the number of inoculums and incubation time. The amount of inoculum tried was $0.5 \mathrm{ml}, 0.75 \mathrm{ml}$, and $1.0 \mathrm{ml}$ and the incubation time applied was 20,30, and 40 days.

During the inoculation, a test tube containing a fungal colony was added into $10 \mathrm{ml}$ sterile distilled water and diluted three times. Furthermore, the amount was taken according to the treatment of $0.5 \mathrm{ml}, 0.75 \mathrm{ml}$, and $1.0 \mathrm{ml}$ and then inoculated onto the enriched substrate with 20,30 days, and 40 days.

The number of treatments includes $0.5 \mathrm{ml}, 0.75 \mathrm{ml}, 1.0 \mathrm{ml}$, those without inoculum (control), three incubation periods (20, 30 , and 40 days), and five repetitions. Subsequently, the cellulose content and lignin levels were analyzed. 


\section{Analysis of cellulose and lignin}

The dry sample in the form of flour was weighed to $1 \mathrm{~g}$ and placed in a gauze Erlenmeyer, $150 \mathrm{ml}$ of distilled water was added and then refluxed at $100^{\circ} \mathrm{C}$ for 1 hour in a water bath. The reflux was filtered with glass polish and the precipitate was washed with $300 \mathrm{ml}$ of hot water. It was then dried in an oven at $105^{\circ} \mathrm{C}$ to attain a constant weight and transferred into a gauze Erlenmeyer quantitatively. Then, $150 \mathrm{ml}$ of $1 \mathrm{~N}$ sulfuric acid was added, refluxed an hour in a water bath at $100^{\circ} \mathrm{C}$. It was then filtered with a glass maser and washed with distilled water until neutral (about $300 \mathrm{ml}$ of water was needed). Furthermore, the precipitate was heated at $105^{\circ} \mathrm{C}$ until it reached a constant weight and transferred to the Erlenmeyer quantitatively. Also, about $10 \mathrm{ml}$ of $72 \%$ sulfuric acid was left for 4 hours at room temperature. Then $150 \mathrm{ml}$ of $1 \mathrm{~N}$ sulfuric acid was added and refluxed in a water bath at $100^{\circ} \mathrm{C}$ for 1 hour. The product was filtered with a maser funnel and washed with about $400 \mathrm{ml}$ of water until neutral. The precipitate was dried in an oven at $105^{\circ} \mathrm{C}$ until it reached a constant weight and then ignited, the resulting ash was weighed. Furthermore, the cellulose and lignin levels were calculated using the equation below:

$$
\begin{gathered}
\text { Cellulose levels }=(\mathrm{c}-\mathrm{d}) \times 100 \% \\
\text { Lignin levels }=(\mathrm{d}-\mathrm{e}) \times 100 \%
\end{gathered}
$$

\section{Data analysis}

Data for lignin and cellulose in fungal selection were analyzed using one-way ANOVA. Furthermore, the effect of the number of inoculum and incubation time was analyzed with the two-way ANOVA. The Duncan test was adopted for treatment with a significant effect.

\section{RESULTS \& DISCUSSIONS}

\section{Selection of white rot fungi}

The statistical analysis of the effect of five types of fungi on OPEFB lignin levels is shown in Table 1.

Table 1. Lignin and cellulose content of fermented OPEFB

\begin{tabular}{ccc}
\hline Treatment & $\begin{array}{c}\text { Lignin level } \\
\text { (\% dry matter) }\end{array}$ & $\begin{array}{c}\text { Cellulose level } \\
(\% \text { dry matter })\end{array}$ \\
\hline Control & $30.03 \mathrm{c}$ & $6.55 \mathrm{abc}$ \\
Coprinus comatus & $23.41 \mathrm{a}$ & $7.86 \mathrm{~d}$ \\
Pleurotus sajur caju & $27.14 \mathrm{~b}$ & $6.07 \mathrm{ab}$ \\
Lentinus Edodes & $26.05 \mathrm{~b}$ & $7.54 \mathrm{~cd}$ \\
Trametes versicolor & $27.07 \mathrm{~b}$ & $5.63 \mathrm{a}$ \\
Tricodherma sp & $29.99 \mathrm{c}$ & $7.08 \mathrm{bcd}$ \\
\hline Note: different subscribed values indicate a significant difference $(\mathrm{p}<0.05)$
\end{tabular}

Based on Table 1, the five types of white-rot fungi applied to OPEFB have different abilities in degrading lignin at 20 days incubation period. However, the Trichoderma $s p$ treatment was not statistically different from the control, it only decreased lignin levels on average. Furthermore, Coprinus comatus reduced lignin levels by $22.04 \%$, which was the best in the degradation of OPEFB following Lentinus edodes (13.25\%), Trametes Versicolor (9.86\%), Pleurotus sajur-caju (9.62\%), and Trichoderma sp (0.13). \%). Jamila (2013) reported a $7.92 \%$ decrease in the application of
Coprinus comatus on wood dust (11). D'Souza et al. [13] also revealed that white-rot fungi degrade all lignocellulosic material components, including lignin by secreting two types of ligninolytic enzymes, namely LiP and MnP. The lignin degradation of LiP is the main enzyme due to its ability to oxidize non-phenolic units.

The use of fungus for delignification has different results, which include the influence of several factors in the decrease in lignin levels, the type of fungus, and fermented material. Suprapti et al. [14], stated that the ability to decompose wood varies, this depends on its type and the nature of fungus work. Imsya et al. [15] showed that Phanerochaeta crysosporium produced a $47.79 \%$ reduction in lignin. Wang et al. [16], through a study on the Lenzites baeulinus, Trametes Orientalis, Trametes velutina, found that T.velutina provided a reduction in lignin levels of $58 \%$ after 12 weeks of processing. Also, white-rot fungi depolymerize and metabolize lignin to $\mathrm{CO}_{2}$ and $\mathrm{H}_{2} \mathrm{O}$ [17]. Srinivasan et al. [18] stated that Basydiomicetes white-rot generally synthesizes three kinds of enzymes, which are vital in the degradation of lignin, namely lignin peroxidase (LiPs), Manganese Peroxidase (MNPs), and Laccase. In general, treatment with the white-rot fungus reduces lignin levels due to the enzymes they produce.

The analysis showed differences in cellulose levels from the treatment of five types of fungi on OPEFB. Statistically, the highest cellulose content was Coprinus comatus (7.86\%), which is different from the control, Pleurotus sajur-caju, and Trametes Versicolor. However, it is not significantly different from Lentinus edodes and Trichoderma sp. In this study, there were increased cellulose levels of about $16.67 \%, 13.13 \%$, and $7.49 \%$, in Coprinus Comatus, Lentinula edodes, Trichoderma $s p$., respectively. The most significant decrease occurred in Trametes Versicolor (14.05\%) and Pleurotus sajur-caju (7.33\%). Similarly, Donggeng [19] reported that the use of Colombian unidentified lipophilic hymenomycetes on palm fibers obtained higher cellulose levels than controls. Increased cellulose levels suggest that Coprinus comatus, Lentinula edodes, and Trichoderma sp. do not produce or use cellulose during fermentation. Furthermore, OPEFB cellulose was not degraded, however, a reasonable number of lignocellulose components has the potential to be broken down into lignin and cellulose. Therefore, a separate cellulose component from lignin needs to be added. Meanwhile, cellulose is thought to have originated from the fungal cell walls.

\section{OPEFB lignin and cellulose levels on the different number of inoculum and incubation time}

Based on the results, the levels of lignin produced after fermentation with the Coprinus comatus were different, as shown in Tables 2 and 3. Furthermore, the statistical tests on the number of inoculums and the incubation period of each treatment differed significantly. However, there was no interaction found between the two treatments as shown in Table 2.

Duncan's test on the levels of lignin levels for each treatment showed a very significant effect, however, there was no interaction. Table 2 shows that the different incubation periods and the number of inoculums are a result of the various lignin levels. The lowest lignin levels were inoculum of $0.5 \mathrm{ml}$ (24.75) followed by control (26.37), an inoculum of $1.0 \mathrm{ml}$ (27.25), and $0.75 \mathrm{ml}$ (27.83). Furthermore, there was a decrease in lignin levels of $0.5 \mathrm{ml}$ inoculum by $6.17 \%$. This has no significant difference compared to the control treatment, 
however, it differs significantly from $0.75 \mathrm{ml}$ and $1.0 \mathrm{ml}$ inoculums. Statistically, the incubation period between 20 and 30 days as well as 20 and 40 days was not significantly different. However, for the 40 days, the lowest lignin levels were obtained (24.40).

Table 2. Lignin levels at different number of inoculum and incubation periods

\begin{tabular}{ccccc}
\hline Treatment & \multicolumn{5}{c}{ Lignin level } \\
\hline Inoculum number20 days30 days40 daysAverage \\
\hline Control & 28.28 & 26.20 & 24.64 & $26.37 \mathrm{ab}$ \\
$0.5 \mathrm{ml}$ & 26.84 & 24.72 & 22.68 & $24.75 \mathrm{a}$ \\
$0.75 \mathrm{ml}$ & 30.80 & 27.20 & 25.50 & $27.83 \mathrm{~b}$ \\
$1.0 \mathrm{ml}$ & 30.42 & 26.58 & 24.76 & $27.25 \mathrm{~b}$ \\
\hline Average & $29.09 \mathrm{~b}$ & $26.18 \mathrm{a}$ & $24.40 \mathrm{a}$ & \\
\hline
\end{tabular}

Table 3 shows that different amounts of inoculum had a very significant effect on cellulose levels. In addition, the best treatment was $0.5 \mathrm{ml}$, which yielded a cellulose content of 9.31 , followed by $1.0 \mathrm{ml}$ inoculum (8.33), control, and $0.75 \mathrm{ml}$ inoculum (7.47) at different incubation periods (20,30, and 40 days). It was also discovered that the cellulose level increased along with the incubation period. The increase in cellulose for the best incubation time was (40 days) was $18.19 \%$. Furthermore, $0.5 \mathrm{ml}$ inoculum produced $9.31 \%$ cellulose of the dry matter and an increase of $18.54 \%$.

Table 3. Cellulose levels at different number of inoculum and incubation periods

\begin{tabular}{ccccc}
\hline Treatment & \multicolumn{4}{c}{ Cellulose level } \\
\hline Inoculum number20 days30 days40 days Average \\
\hline 0 & 7.00 & 7.3 & 8.46 & $7.59 \mathrm{a}$ \\
0.5 & 8.72 & 9.08 & 10.14 & $9.31 \mathrm{~b}$ \\
0.75 & 6.20 & 7.38 & 8.82 & $7.47 \mathrm{a}$ \\
1.0 & 7.80 & 8.28 & 8.91 & $8.33 \mathrm{ab}$ \\
\hline Average & $7.43 \mathrm{a}$ & $8.01 \mathrm{ab}$ & $9.08 \mathrm{~b}$ &
\end{tabular}

Note: different subscribed values indicate a significant difference $(\mathrm{p}<0.05)$

The results showed that the fermentation with Coprinus comatus differs significantly in terms of the specific number of inoculums and incubation periods on the levels of lignin and cellulose of empty oil palm fruit bunches. However, there was no interaction between the two treatments. This study proved that the incubation period and the number of inoculums have a significant effect on delignification. Reddy et al. [7] reported that increasing the number of $P$. ostreatus and $P$. sajor caju fungi would increase cellulolytic enzymes per dry weight of the material. Furthermore, Belewu [8] used the Pleurotus sajor саju in sawdust and cotton residue with 60 days incubation period, the lignin content and the remaining cotton were reduced from $44.36 \%$ to $25.53 \%$, and $20 \%$ to $14.2 \%$, respectively. The reduction in cellulose also occurred at a lower rate from $31.99 \%$ to $30.89 \%$ for sawdust and 23.72 to $21.8 \%$ for the remaining cotton. This indicates that fungi are more likely to break down lignin than hemicellulose or cellulose.

Fadilah et al. [20] found that the most significant results with an $81.4 \%$ decrease rate occur at a 30days incubation period followed by $23 \%$ cellulose levels. Furthermore, Anita et al. [21] stated that the 4 weeks incubation period of a single culture $P$. ostreatus is more advantageous for bagasse pretreatment. This is due to the relatively high level of lignin degradation $(17.95 \%)$. The degradation rate of cellulose was not too high $(11.00 \%)$ compared to mixed culture. However, the optimum amount of inoculum at pretreatment $T$ Versicolor was $15 \%$, while $P$ ostreatus was $10 \%$. In addition, the whiterot fungi are the most efficient group due to their ability to degrade lignin compared to the brown and soft rot, which are limited to hemicellulose and cellulose degradation [22]. An increase in cellulose levels suggests that the Coprinus comatus uses only lignin as an energy source in fermentation. Therefore, there is an increase in cellulose, which emerges from the fungus itself. Donggeng [19] stated that the addition of cellulose comes from the cell walls of fungi. This is consistent with the statement of Kusumaningsih [23] that the components of the fungal cell wall include the chitin, beta-1,3 glucan, and the mannoprotein layer.

This study illustrated that white-rot fungi such as Coprinus comatus tend to degrade lignin compared to cellulose. Furthermore, the decrease in lignin levels in empty oil palm fruit bunches is due to the active release of ligninolytic enzymes during fermentation. Coprinus comatus which was applied to empty fruit bunches contributed to the utilization of agro-industrial waste such as empty oil palm fruit bunches in reducing lignin content. Subsequently, it is utilized by livestock for growth. Also, Coprinus comatus, which is a part of the white-rot fungi group has the ability to degrade lignin as high as other fungi [11]. White rot mold increases the nutritional value of corn cobs used as animal feed and also depolymerizes oxidative by secreting several enzymes lignin peroxidase $(\mathrm{LiP})$, manganese-peroxidase $(\mathrm{MnP})$, and laccase $[18,24]$. Furthermore, ligninolytic fungi use lignin as the only energy source and carbon for growth. as well as polysaccharides that are present in lignocellulosic substrates [25]. However, it is believed that the fermentation with Coprinus comatus does not secrete cellulase enzymes.

This study will contribute to the fermented empty oil palm fruit bunches by white-rot fungi as animal feed. The result showed that the higher the cellulose content of the ingredients, the better the animal feed. Furthermore, Haryanto [26] reported that cellulose and hemicellulose are polymers of glucose and xylose, respectively that are converted into free fatty acids by the activity of rumen microbial enzymes, which is a source of energy for livestock. According to Yanuartono et al. [27], the use of biological methods for utilizing fungi is able to improve the quality of feed from agricultural waste due to its ability to degrade lignin through the synthesis of ligninolytic enzymes. Furthermore, the use of fungi in biological methods is safe, environmentally friendly, easy to work with, and inexpensive.

These results were different from previous studies. The limitation is the lack of included laboratory analysis such as protein content, crude fiber, and other components that further explains the results.

\section{CONCLUSION}

This study shows that Coprinus comatus is the best of the five fungi applied to empty oil palm fruit bunches. Furthermore, the most significant method for enhancing the value of empty palm oil fruit bunches is the use of $0.5 \mathrm{ml}$ Coprinus comatus in an inoculum with an incubation period of 40 days. This is because it reduces lignin and increases cellulose levels. Conclusively, the use of white-rot fungus increases the nutritional value of empty oil palm fruit bunches. 


\section{ACKNOWLEDGMENT}

The authors are grateful to the Rector Alkhairaat University for funding this study.

\section{REFERENCES}

[1] Statistik, B.P. (2018). Statistik kelapa sawit Indonesia 2017. Jakarta (ID): Badan Pusat Statistik.

[2] Elisabeth, J., Ginting, S.P. (2003). Pemanfaatan hasil samping industri kelapa sawit sebagai bahan pakan ternak sapi potong. Prosiding Lokakarya Nasional Sistem Integrasi Kelapa Sawit-Sapi. Bengkulu, 9-10.

[3] Ishola, M.M., Millati, R., Syamsiah, S., Cahyanto, M.N., Niklasson, C., Taherzadeh, M.J. (2012). Structural changes of oil palm empty fruit bunch (OPEFB) after fungal and phosphoric acid pretreatment. Molecules, 17(12): 14995-15012. https://doi.org/10.3390/molecules171214995

[4] Manurung, H. (2011). Pabrik minyak kelapa Sawit (PMKS) berawasan lingkungan melalui pemanfaatan limbah. In: Prosiding Seminar Naisonal Kimia. Medan: USU, pp. 89-95.

[5] Novital, I., Novia, N., Hermansyah, H. (2012). Pengaruh Laju Alir Oksigen dan Waktu Kontak terhadap Delignifikasi Tandan Kosong Kelapa Sawit dengan Metode Ozonasi. In: Prosiding seminar Nasional Avoer IV. Palembang: Universitas Sriwijaya;. pp. 341-347.

[6] Sarnklong, C., Cone, J.W., Pellikaan, W., Hendriks, W.H. (2010). Utilization of rice straw and different treatments to improve its feed value for ruminants: A review. AsianAustralasian Journal of Animal Sciences, 23(5):680-692. https://doi.org/10.5713/ajas.2010.80619

[7] Reddy, G.V., Babu, P.R., Komaraiah, P., Roy, K.R.R.M., Kothari, I.L. (2003). Utilization of banana waste for the production of lignolytic and cellulolytic enzymes by solid substrate fermentation using two Pleurotus species (P. ostreatus and P. sajor-caju). Process Biochemistry, 38(10): 1457-1462. https://doi.org/10.1016/S00329592(03)00025-6

[8] Belewu, M.A. (2006). Conversion of masonia tree sawdust and cotton plant by product into feed by white rot fungus. African Journal of Biotechnology, 5(19). Available from: https:/www.ajol.info/index.php/ajb/article/view/55847

[9] Ermawar, R.A., Yanto, D.H.Y., Fitria, H.E. (2006). Lignin degradation content in rice straw pre-treated by white-rot fungi. J Widya Riset, 9(3): 197-202.

[10] Islamiyati, R. (2013). Islamiyati R. Efisiensi Penggunaan Pakan Dan Pertambahan Bobot Badan Kambing Lokal Dengan Pakan Jerami Jagung Yang Diinokulasi Fungi Trichoderma sp. Dan Diperkaya Daun Gamal.

[11] Mustabi, J., Natsir, A. (2013). Pemanfaatan Jamur Pelapuk Putih Dalam Meningkatkan Kualitas Nutrisi Jerami Padi. Hasanuddin University.

[12] Hermiati, E., Risanto, L., Anita, S.H., Aristiawan, Y., Hanafi, A., Abimanyu, H. (2014). Sakarifikasi Serat Tandan Kosong dan pelepah Kelapa Sawit Setelah Pretreatment Menggunakan Kultur Campuran Jamur Pelapuk Putih Phanerochaete chrysosporium dan Trametes versicolor. Jurnal Penelitian Hasil Hutan, 32(2): 111-122. https://doi.org/10.20886/jphh.2014.32.2.111122
[13] D'Souza, T.M., Boominathan, K., Reddy, C.A. (1996). Isolation of laccase gene-specific sequences from white rot and brown rot fungi by PCR. Applied and Environmental Microbiology, 62(10): 3739-3744. https://doi.org/10.1128/aem.62.10.3739-3744.1996

[14] Suprapti, S., Djarwanto, D., Hudiansyah, H. (2007). Ketahanan Lima Jenis Kayu terhadap Tigabelas Jamur Perusak Kayu. Jurnal Penelitian Hasil Hutan, 25(1): 75 83. https://doi.org/10.20886/jphh.2007.25.1.75-83

[15] Imsya, A., Laconi, E.B., Wiryawan, K.G., Widyastuti, Y. (2013). In vitro digestibility of ration containing different level of palm oil frond fermented with Phanerochaetae chrysosporium. Media Peternakan, 36(2): 131-131. https://doi.org/10.5398/medpet.2013.36.2.131

[16] Wang, P., Souma, K., Okamoto, H., Yano, T., Nakano, M., Furudate, A., Masuko, T. (2014). Effects of addition of lactobacillus plantarum and enterococcus faecium inoculants to high-nitrogen fertilized timothy (Phleum pratense L.) on fermentation, nutritive value, and feed intake of silage. American Journal of Plant Sciences, 5(26): 3889. https://doi.org/10.4236/ajps.2014.526407

[17] Kaal, E.E., Field, J.A., Joyce, T.W. (1995). Increasing ligninolytic enzyme activities in several white-rot basidiomycetes by nitrogen-sufficient media. Bioresource Technology, 53(2): 133-139. https://doi.org/10.1016/0960-8524(95)00066-N

[18] Srinivasan, C., Dsouza, T.M., Boominathan, K., Reddy, C.A. (1995). Demonstration of laccase in the white rot basidiomycete Phanerochaete chrysosporium BKMF1767. Applied and Environmental Microbiology, 61(12): 4274-4277. https://doi.org/10.1128/aem.61.12.4274-4277.1995

[19] Donggeng, S.S. (2002). Pengaruh Penggunaan Phmrerocaeta crysossporium dan Colombian Unidentrfied Lignophilic Hymenomycetes (CULH) dalam Mendegradasi Lignoselulosa sebagai Upaya untuk Meningkatkan Nilai Nutrisi Pakan Serat. http://repository.ipb.ac.id/handle/123456789/42452

[20] Fadilah, F., Distantina, S., Artati, E.K. (2008). Biodelignifikasi batang jagung dengan jamur pelapuk putih Phanerochaete chrysosporium. Ekuilibrium, 7(1): 7-11. https://doi.org/10.20961/ekuilibrium.v7i1.49497

[21] Anita, S.H., Fajriutami, T., Fitria, E.R., Yanto, D.H.Y., Hermiati, E. (2011). Pretreatment Trametes versicolor dan Pleurotus ostreatus pada bagas untuk produksi bioetanol. J Teknol. Indones, 34: 33-39.

[22] Madadi, M., Abbas, A. (2017). Lignin Degradation by Fungal Pretreatment: A Review. J Plant Pathol Microbiol, 8(2): 1-6. https://doi.org/10.4172/2157-7471.1000398

[23] Kusumaningsih, T., Masykur, A., Arief, U. (2004). Pembuatan kitosan dari kitin cangkang bekicot (Achatina fulica). Biofarmasi, 2(2): 64-68.

[24] d'Acunzo, F., Baiocco, P., Galli, C. (2003). A study of the oxidation of ethers with the enzyme laccase under mediation by two N-OH-type compounds. New Journal of Chemistry, 27(2): 329-332. https://doi.org/10.1039/B210978F

[25] Hammel, K.E. (1996). Extracellular free radical biochemistry of ligninolytic fungi. New Journal Chemistry, 20: 195-198.

[26] Haryanto, B. (2014). Maximizing utilization of energy from crop by-products. WARTAZOA. Indonesian Bulletin of Animal and Veterinary Sciences, 24(1): http://dx.doi.org/10.14334/wartazoa.v24i1.1023 
[27] Yanuartono, Purnamaningsih, H., Indarjulianto, S., Nururrozi, A., Raharjo, S., Haribowo, N. (2019). Biological treatment by utilizing fungi to improve the quality of animal feed from agricultural byproduct.

Jurnal Peternakan Sriwijaya, 8(2): 18-34.

https://doi.org/10.33230/JPS.8.2.2019.10227 